\title{
Antimicrobial activity extracts from three species of fresh water algae and used against some pathogenic microorganisms and analysis of minerals in algal species
}

\begin{tabular}{ccc}
\hline Kwestan Hassan Sdiq $^{1}{ }^{*}$ & Trifa Kamal Jalal Farkha $^{2}$ & Awara Khdir Smail $^{3}$ \\
\hline Abstract &
\end{tabular}

Background and objective: Algal organism are affluent funds for pharmaceuticals on the basses of presence some primary, secondary metabolic content and The distinctive Chemical compounds which have the biological activity such as toxicity, antibacterial, antifungal, antiviral, antitumor and other specific activities. the algae species antimicrobial activities have trivial effective side and have precious therapeutic potential rather than the synthetic antimicrobials objective of the study was to determine antimicrobial activity and mineral analysis of crude extract of three fresh water algal species which isolated from Dukan lake water stations then comparison their inhibition activity against 2 types of pathogenic bacteria and one type of fungus species with negative (organic solvent) and positive control (antibiotic and antifungal). Three fresh water algal species (Chlorella vulgaris), (Chara vulgaris) and (Spirogyra pratensis).

Methods: The algal species were cultivated was extracted by using 3 different organic solvents (Ethanol, Ethylacetate and Chloroform) then used to produced their inhibitory effect against 2 bacterial pathogen (Escherichiacoli) gram negative and (Staphylococcus aureus) gram positive and one fungus species (Aspergillusniger) by using agar well diffusion methods.

Results: The obtained results elevated that the ethanol and ethyl acetate extract of all algal species in this study showed antimicrobial activity against all organisms tested except Staphylococcus aureus which was resistant against the ethanol extract of Chlorellavulgaris while the chloroform extract of Chara vulgaris and Spirogyrapratensis having the antibacterial activity only against the gram negative bacteria (Escherichia coli).

In the end of this study analysis for three species of freshwater algae, shows that contain these minerals ( $\mathrm{Na}, \mathrm{K}, \mathrm{Ca}, \mathrm{Mg}, \mathrm{Ni}, \mathrm{Fe}, \mathrm{Zn}, \mathrm{Mn}, \mathrm{Cu}, \mathrm{Pb}, \mathrm{Al}, \mathrm{Cd}, \mathrm{Cr}$, and $\mathrm{Co}$ ) by using Flame atomic absorption spectrophotometer.

Conclusion: These results of algae species in these study give an indication of the presence promising antimicrobial compounds.

Keywords: Antimicrobial activity; Algal species; Mineral analysis.

\section{Introduction}

Algae are a large and diverse group of organisms from which a wide range of secondary metabolites have been isolated. A number of these compounds possess biological activity such as toxicity, antibacterial, antifungal, antiviral, antitumor and other specific activities. Many bioactive and pharmacologically active substances have been isolated fromalgae. ${ }^{1}$ Algal organisms are rich source of novel and biologically active primary and secondary metabolites and also They contain more than sixty trace elements including minerals, proteins, iodine, bromine and many bioactive substances. ${ }^{2}$ To date, many chemically unique compounds of fresh water origin with various biological activities have been isolated and some of them are under investigation while some

${ }_{1}^{1}$ Department of Medical Microbiology, College of Health Sciences, Hawler Medical University, Erbil, Iraq.

2 Department of Biology, Faculty of Science and Science Education, School of Science, Sulaimani University, Iraq.

${ }^{3}$ Department of Biology, Faculty of Science and Health, School of Science, Koya University, Erbil, Iraq.

* Correspondence: kwestan.sdiq@hmu.edu.kr 
are being used to develop new pharmaceutical industry. $3,4,5,6,7$ The cell extracts and active constituents have been shown to have antibacterial activity in vitro against Gram positive and Gram negative bacteria. In addition, a wide range of results of in vitro antibacterial and antifungal activities of extracts of fresh water algae have been reported. ${ }^{8}$ The existence of bioactive compounds in algae is to be expected due to occurrence of these organisms in aquatic natural communities, where an inhibitory interaction occurred between producers and competitors within the same habitat. These metabolites may be synthesized under stress conditions and low growth rate. ${ }^{9}$ The use of antimicrobial drugs against infectious diseases has certain limitations due to changing patterns of resistance in pathogens and side-effects they produce. These limitations demand for improved pharmacokinetic properties, which continued research for new antimicrobial compounds for the development of drugs. ${ }^{10}$

\section{Methods}

Isolation and identification of algal species:

Three algal species (Chlorellavulgaries, Charavulgaris and Spirogyrapratensis) were isolated from dukan lake have been identified by using those key of identification and references. ${ }^{11,12,13}$

\section{Culturing of algae:}

Uni-algal culture was obtained culturing algae, the surface of each media plates was inoculated with $1 \mathrm{ml}$ of sampled water, the inoculum distributed with a sterile spreader or streaking using a sterile loop. The inoculated plates were incubated in a controlled temperature and illumination, (White fluorescent tubes) ${ }^{14}$ In the present study 1000 lux for each 10 plates, temperature is $25 \pm 3$ and the photo period time of 16 light and 8 dark time were used. Aggregated colonies were observed on the surface of plates. Part from these colonies was stroke on other plates. Each subculture was examined at different intervals, this method was repeated till a uni-algal culture or cultures have been gained. ${ }^{15}$

\section{Cultivation of the purified algae:}

A small part of uni-algal culture which was microscopically confirmed as uni-algal culture was transferred into media nutrient solutions within a $250 \mathrm{ml}$ sterile conical flask to get appropriate growth and incubated for 2-3 weeks according to method of Jawad. ${ }^{16}$ Then the cultivated algae was centrifuged by centrifuge $10000 \mathrm{rpm}$ for 15 minute the algae pellet was collected and dried by oven at $40^{\circ} \mathrm{C}$ and the dried algae was preserved in plastic bottle in refrigerator .In order to sustain the viability of the uni-algal growth, these cultures were renewed every two weeks by sub culturing into another media nutrient solution. ${ }^{17}$

\section{Collection of macro algae:}

Algal blooms samples were collected from water of studied area. The blooming of Algal biomass was handpicked, samples were cleaned of epiphytes, extra generous matter and necrotic particles are removed. , and placed in clean plastic containers with their original water and brought to the laboratory, they identified as Spirogyra and Chara, Then the samples were rinsed with distilled water and shaded dried then cut into small pieces and powdered in a mixer grinder and dried at $40^{\circ} \mathrm{C}$ in an oven for 2-3 days till the dry weight was constant. ${ }^{7}$

\section{Preparation of crude extract of algae:}

The samples of algae were dried at room temperature under shade and powdered. The powder was dissolved with three different organic solvent (ethanol, ethyl acetate and chloroform) (1/10w/v) and soaked overnight. The solvent extracts were centrifuged at $2000 \mathrm{rpm}$ for $15 \mathrm{~min}$ (sigma). The supernatant which contained polyphenols was recovered. The pellet was dissolved twice in same solvent extract $(1 / 10 \mathrm{w} / \mathrm{v})$. The supernatants were filtered through a watt man filter paper and concentrated by using Rotary evaporator $\left(40-45^{\circ} \mathrm{C}\right)$. The dried extract was dissolved in the same organic solvent and stored at 
$4^{\circ} \mathrm{C}$ before analyzing. ${ }^{18}$

\section{Antimicrobial activity:}

All organisms used for antimicrobial activity obtained from Media Diagnostic Center, in Kurdistan region in Erbil, crude extract was used for antimicrobial activity. ${ }^{19}$ The crude solvent extract were tested against the gram positive bacterial species; Staphylococcus aureus "ATCC:25923" and the gram negative bacterial species; Escherichia coli "ATCC:25922" and one fungus Aspergillus niger"ATCC:16404". The inoculated plates were incubated for $24 \mathrm{~h}$ at $37^{\circ} \mathrm{C}$ for bacteria and inoculated for 3 days at $30^{\circ} \mathrm{C}$ for fungi. ${ }^{17,20}$ The turbidity of the suspension of the activated broth which used for culturing compare with 0.5 McFarland standard solutions $(1.5 \times 10$ $8 \times 10$ cell $/ \mathrm{ml}$ ) then $1 \mathrm{ml}$ of bacterial suspension was added to $9 \mathrm{ml}$ of sterile normal saline after that added to a Petri dish agar. $1 \mathrm{ml}$ of the prepared bacterial suspension was added to the Petri dish. ${ }^{21}$ Three plates were tested per target microorganism. The plates were left $2 \mathrm{~h}$ at $4 \circ \mathrm{C}$ then incubated at $37 \circ \mathrm{C}$ for $24 \mathrm{~h}$ and examined for zones of inhibition around thedisc. $^{22}$

Antibacterial assay:

-For antibacterial activity the bioactivities of algae were tested by agar well diffusion method with the extract of algae species. $^{23,24}$

-For inoculum preparation and assay of antibacterial activity, Mueller Hinton Agar was used.

At $\mathrm{pH} 7.4 \pm 0.2$ after autoclaving at $121^{\circ} \mathrm{C}$ for $15 \mathrm{~min}$. poured in petri dishes, inoculated with $0.1 \mathrm{ml}$ of a $24 \mathrm{hr}$. broth culture of test bacteria. Four wells of $6 \mathrm{~mm}$ each were made onto the medium using a cork borer. Petri dishes left for 15 minutes until bacteria were absorbed to medium, then extracts $(50 \mu \mathrm{l})$ were poured into wells. The agar plates were incubated at $37^{\circ} \mathrm{C}$ for $24 \mathrm{hr}$. and the inhibition zones measured with a ruler and compared with the negative control well (well containing only the respective solvent) and erythromycin $(15 \mu \mathrm{g})$ as positive control after $24 \mathrm{hr}$. Assays were run in triplicate. After incubation the inhibition zones around the wells as an evidence of antibacterial activity were measured underside and expressed in millimeter. ${ }^{9,17,25}$

Anti-fungal assay:

Antifungal activity was evaluated by agar well diffusion method. For antifungal activity $20 \mathrm{ml}$ of Potato dextrose agar were poured in petri dishes after solidify and then inoculated with $0.1 \mathrm{ml}$ of 5 days glucose peptone broth culture of test fungi and yeast. The agar plates inoculated with the test microorganisms were incubated for $1 \mathrm{~h}$ before placing extract, following this wells of $25 \mu \mathrm{l}$ of crude extract of algae were applied on agar medium. After incubation all plates were observed for zones of growth inhibition, and the diameters of these zones were measured in millimeters. All tests were performed on sterile conditions in duplicate and repeated three times. Itraconazole was used as positive control, and a solvent extracts as negative control. ${ }^{9,26}$

Mineral analysis:

Samples for mineral analysis were dissolved in dilutes nitric acid and analyzed through flame atomic absorption spectrophotometer, the procedures described by. ${ }^{27}$

\section{Results}

\section{Antimicrobial activity:}

Three algal species were tested for antimicrobial activity against two pathogenic bacteria and one fungus species (Table 1), the degree of microbial activity was varied with references to algal species, type of solvent used for extraction, and the type of microorganism. Antimicrobial activity of crud extracts were evaluated using agar well diffusion method in comparison to the reference drug antibiotic (Erythromycin) for bacterial strains and antifungal (Itroconazol) for fungus .The ethanol extract of Chlorella vulgaris showed antimicrobial activity against E. coli and Aspergillusniger which their inhibition zone was $13.5 \mathrm{~mm}$ and 
$11.9 \mathrm{~mm}$ in diameter respectively, while Staphylococcus aureus, was resistant against chlorella vulgaris. Ethanol extract of Chara vulgaris and Spirogyra pratensis showed antimicrobial activity for all microorganisms which used in this study .The highest inhibition zone of was recorded by Chara vulgaris crud extract against Staphylococcus aureus with the inhibition zone of $17.3 \mathrm{~mm}$ in diameter and the minimum inhibition zone was recorded by Spirogyra pratensis which was $7.0 \mathrm{~mm}$ in diameter against Staphylococcus aureus. The ethyl acetate extract of Chlorella vulgaris and Chara vulgaris showed antimicrobial activity against all microorganisms which used in the study and the highest inhibition zone was recorded against the gram positive bacteria which were $14.3 \mathrm{~mm}$ and $16.0 \mathrm{~mm}$ in diameter respectively, While the ethyl acetate extract of Spirogyra showed antibacterial activity against both gram positive and gram negative bacterial strains which was $12.5 \mathrm{~mm}$ and $10.5 \mathrm{~mm}$, respectively. Chloroform extract of Chlorella vulgaris was failed to inhabit the growth of any microorganisms used during the study. While the chloroform extract of Chara vulgaris and Spirogyra pratensis inhibited the growth of $E$. coli which was $10.3 \mathrm{~mm}$ and $11 \mathrm{~mm}$, respectively. From the result in Table1 It was clear that Chara vulgaris extracted by ethanol showed a highest activity against Aspergillusniger which was reached $18.5 \mathrm{~mm}$ in diameter. The results of positive control for erythromycin were $8.7 \mathrm{~mm}$ for gram positive bacteria and $9.7 \mathrm{~mm}$ for gram negative bacteria. The result for Itraconazole was recorded $19.0 \mathrm{~mm}$ in diameter of inhibition zone against Aspergillusniger.

Table 1: Antimicrobial activity of three different extract against.

\begin{tabular}{lccc}
\hline $\begin{array}{l}\text { Algae +Controls } \\
\text { Staph.aureusE.coliAsp.niger }\end{array}$ & \multicolumn{3}{c}{ Inhibition zone (mm) of Microrganisms } \\
\hline Chlorella culgarisethanol & 0.00 & 13.5 & 11.9 \\
Ethyle acetate & 14.3 & 13 & 10.5 \\
Chloroforn & 0.00 & 0.00 & 0.00 \\
Chara vulgaris ethanol & 17.3 & 16.5 & 18.5 \\
Ethyle acetate & 16 & 13.5 & 17 \\
Chloroforn & 0.00 & 11 & 0.00 \\
Spirogyra pratensisethanol & 7 & 13.5 & 10 \\
Ethyle acetate & 12.5 & 10.5 & 12 \\
Chloroforn & 0.00 & 10.3 & 0.00 \\
Erythromycin and Itraconazol & 8.7 & 9.7 & 19 \\
(Positive control) & & & 0.00 \\
Negative control ethanol & 0.00 & 0.00 & 0.00 \\
Ethyle acetate & 0.00 & 0.00 & 0.00 \\
Chloroforn & 0.00 & 0.00 & \\
\hline
\end{tabular}


The Second Scientific Conference for The College of Pharmacy/Hawler Medical University, (13th - 14th of November 2019, Dedeman Hotel - Erbil, Kurdistan)

Mineral analysis: mineral analysis of all algal species,

In Table 2, we summarize our results of analysis by diluted nitric acid

Table 2: Mineral analysis of algae $\mu \mathrm{g} / \mathrm{gm}$.

\begin{tabular}{|c|c|c|c|}
\hline Minerals & Chlorella & Chara & Spirogyra \\
\hline Sodium (Na) & 500 & 380 & 270 \\
\hline Potassium (K) & 560 & 180 & 105 \\
\hline Calcium(Ca) & 600 & 85 & 73 \\
\hline Cobalt (Co) & 1.84 & 1.20 & 0.72 \\
\hline Chromium(Cr) & 20.3 & 6.20 & 3.41 \\
\hline Copper (Cu) & 3.20 & 1.25 & 2.00 \\
\hline Iron(Fe) & 1625 & 521 & 422 \\
\hline Magnesium(Mg) & 5241 & 1896 & 1284 \\
\hline Zink( Zn) & 80.5 & 60.24 & 48.35 \\
\hline Manganese (Mn) 18.65 & 65.2 & 22.3 & 18.65 \\
\hline Cadmium (Cd) & 1.31 & 0.54 & 0.21 \\
\hline Aluminum (Al) & 210.2 & 55.4 & 20.1 \\
\hline Nickel ( Ni) & 1.27 & 1.32 & 0.95 \\
\hline Lead $(\mathrm{Pb})$ & 2.31 & 0.99 & 0.84 \\
\hline
\end{tabular}

From the results appear that contain high amount $(5241 \mu \mathrm{g} / \mathrm{gm}) \mathrm{Mg}$ in Chlorella, followed by $(1625 \mu \mathrm{g} / \mathrm{gm}) \mathrm{Fe}$ in Chlorella, followed by $(600 \mu \mathrm{g} / \mathrm{gm}) \mathrm{Ca}$ in Chlorella, while minimum amount $(0.21 \mu \mathrm{g} / \mathrm{gm}) \mathrm{Cd}$ in Spirogyra. 


\section{Discussion}

Chlorella vulgaris extracted by ethanol showed moderate antibacterial activity against the gram negative $E$. coli. While ethyl acetate extract of Chlorellavulgaris, showed antimicrobial activity against all microorganisms which were used in this study. The chloroform extract of Chlorella vulgaris was failed to show any bioactivities against all microorganisms used during the study. Several researchers proved that the fresh water algae have anti-microbial activity. ${ }^{17,23,28,29,30,31,32,33}$ The ethanol extract of Chlorella vulgaris showed the antibacterial activity against $E$. coli which have the inhibition zone was $13.5 \mathrm{~mm}$ in diameter this result was similar to the results recorded by which was $18 \mathrm{~mm}$ and $20.5 \mathrm{~mm}$, respectively. ${ }^{34,35}$ While Staphylococcus aureus, was resistant this result was agreed to the result obtained by (Al-Wathnani) using the mixture of three solvents methanol:acetone:diethylether as $5: 2: 1 \mathrm{v} / \mathrm{v}$. and disagree with the result of ( Vishnu and Sumathi, Abdin and Hala). ${ }^{4,23,34}$ Aspergillusniger inhibition zone was reached $11,9 \mathrm{~mm}$ in diameter this result similar to that investigated by (Ghasmeni, Abdin and Hala). ${ }^{4,35}$ Ethanol and ethyl acetate extracts of Spirogyra pratensis showed the antibacterial activity against both gram positive and gram negative bacterial strains, inhibition zones recorded was $12.5 \mathrm{mmand} 10.5 \mathrm{~mm}$ respectively, and the antifungal activity was $12 \mathrm{~mm}$ in diameter, agreement to the result of those references. ${ }^{35,36}$ Generally gram negative bacteria was resistant against antibiotic compared with gram positive bacteria because of their more complex multi layered cell wall structure, which makes it more difficult for the active compound to penetrate. ${ }^{37}$ Results of Spirogyra extract by chloroform revealed that the spirogyra produce antibacterial agent against the gram-negative bacteria (E. coli) inhibition zone recorded was $10.3 \mathrm{~mm}$ in diameter; this result was agreed with the result of (Hemavani, et al.,.). ${ }^{19}$
While chloroform extract of Chlorella vulgaris was failed to show growth inhibition against any microorganisms which used during the study. Low antimicrobial activity was detected in the chloroform extracts. This probably was because of polar nature of the active components. It revealed that the chance of producing antimicrobial activity is higher in ethanol and ethyl acetate extracts than chloroform. ${ }^{38}$ Indicated that there are many factors affecting the algae extraction. Among them, extraction temperature, the concentration and extraction time are key factors, intraspecific variability in the production of secondary metabolites occasionally related to seasonal variations, differences in the extraction protocols used to recover the active metabolites as well as differences in the assay methods may be causes the variation between our results and those from other studies.

\section{Conclusion}

Antimicrobial activity was carried out against two bacterial pathogens (Escherichiacoli) gram negative bacteria and (staphylococcus aureus) gram positive bacteria and one fungus species (Aspergillusniger). The obtained results elevated that the ethanol and ethyl acetate extract of all species in this study showed antimicrobial activity against all organisms tested except Staphylococcus aureus which was resistant against the ethanol extract of Chlorellavulgaris while the chloroform extract of Chara vulgaris and Spirogyrapratensis having the antibacterial activity only against the gram negative bacteria (Escherichia coli). These results of algae species in these study give an indication of the presence promising antimicrobial compounds. Further phytochemical studies are needed to elucidate the components responsible for antimicrobial activity of these extracts against human pathogen. 


\section{References}

1. Rout $S$ and Kumar A. A review on the potentiality of marine seaweeds as a medicinal source. World journal of pharmacy and pharmaceutical sciences 2015; 4(10).

2. Asthana RK, Tripathi MK, Srivastava A, Singh, AP, Singh SP, Nath G. Isolation and identification of a new antibacterial entity from the antarcticcyanobacterium Nostoc CCC 537. J Appl Phycol 2009; 21:81-8.

3. Choudhary S, Sree A, Mukherjee SC, Patnaik P, Bapuji M. In vitro antibacterial activity of extracts of selected marine algae and mangroves against fish pathogens. Asian Fish Sri 2005; 18:285-94.

4. Abedin RMA, Hala MT. Antibacterial and antifungal activity of cyanobacteria and green microalgae. Evaluation of medium components by Placketi-Burman design for antimicrobial activity of. Spirulinaplatensis. Glob J Biotechnal Biochem 2008; 3:22-31.

5. Desbois AP, Lebi T, Yan L, Smith VJ. Isolation and structuralcharacterisation of two antibacterial free fatty acids from the marine diatom, Phaeodactylumtricornutum. Appl Microbiol Biotechnol 2008; 81:755-64.

6. Kamble SM, Chavan AM. Antibacterial activity of some fresh water algae. J Exp Sci 2010; 1(2):56.

7. Elsie $\mathrm{BH}$, DhanaRajan MS. Evaluation of antimicrobial activity and phytochemical screening of Gelidiumacerosa. Journal of Pharmaceutical Sciences and Research 2010; 2(11):704.

8. Naik Ansari A, Hemavani C, Thippeswamy B. Evaluation of antimicrobial property of Spirogyra species. Int multidisciplinary Res J 2012; 2:1315.

9. Patil KJ, Patil VA, Mahajan SR, Mahajan RT. Bio-activity of algae belonging to Bhusawal region, Maharashtra. Current Botany 2011 Feb 24.

10. Al-Haj NA, Mashan NI, Shamsudin MN, Mohamad H, Vairappan CS, Sekawi Z. Antibacterial activity in marine algae Eucheumadenticulatum against Staphylococcus aureus and Streptococcus pyogenes. Research Journal of Biological Sciences 2009; 4(4):519-24.

11. Prescott GW. Algae of the western great lakes area, Otto Kaetz Science publishers. W German 1982.

12. Komárek JT, Anagnostidis K. Cyanoprokaryota. I -Chroococcales, II-Oscillatoriales, III-Nostocales. Stigonematales, Stuttgart 1989.

13. Krammer K. Bacillariophyceae 2. Teil: Bacillariaceae, Epithemiaceae, Surirellaceae. Subwasserflora von Mitteleuropa. 1988.

14. Hreeb KK, AL-Asadi MS, Talal AA. Organic manure (horses stool) affects the green alga Chlorella vulgaris Beijernick growth. Journal of Misan Researches 2007; 3(6):15-28.
15. Littler MM, Littler MM, Stein-Taylor JR, Littler DS, editors. Handbook of phycological methods: volume 4: ecological field methods: macroalgae. Cambridge University Press 1985.

16. Jawad AM. Interaction between cyanobacteria and other micro-organisms. Ph.D. Thesis. Liverpool University. England 1982.

17. Abdo SM, Hetta MH, Samhan FA, Din RE, Ali GH. Phytochemical and antibacterial study of five freshwater algal species. Asian journal of plant sciences 2012; 11(3):109.

18. Cho SH, Kang SE, Cho JY, Kim AR, Park SM, Hong YK, Ahn DH. The antioxidant properties of brown seaweed (Sargassumsiliquastrum) extracts. Journal of medicinal food 2007; 10(3):479-85.

19. Hemavani C, Thippeswamy B. Evaluation of antimicrobial property of Spirogyra species. International Multidisciplinary Research Journal. 2012; 2(2).

20. Zakaria NA, Ibrahim D, Sulaiman SF, Supardy NA. Journal of Chemical and Pharmaceutical Research. J Chem 2011; 3(3):182-91.

21. Medina-Jaritz NB, Perez-Solis DR, Ruiloba de Leon SL, Olvera-Ramírez R. Antimicrobial activity of aqueous and methanolic extracts from Arthrospira maxima. Science against microbial pathogens: communicating current research and technological advances. A. Méndez-Vilas (Ed.). 2011:1267-71.

22. Al-Wathnani H, Ara I, Tahmaz RR, Al-Dayel TH, Bakir MA. Bioactivity of natural compounds isolated from cyanobacteria and green algae against human pathogenic bacteria and yeast. Journal of Medicinal Plants Research. 2012; 6(18):3425-33.

23. Bauer AW, Kirby WM, Sherris JC, Turck M. Antibiotic susceptibility testing by a standardized single disk method. American journal of clinical pathology 1966 ; 45(4):493-6.

24. TAŞKIN E, Taşkin E, Öztürk M. Inhibitor Activities of some seaweeds from the Aegean Coast of Turkey. Journal of Applied Biological Sciences 2011; 1(1):11-5.

25. Karabay-Yavasoglu NU, Sukatar A, Ozdemir G, Horzum Z. Antimicrobial activity of volatile components and various extracts of the red alga Janiarubens. Phytotherapy Research: An International Journal Devoted to Pharmacological and Toxicological Evaluation of Natural Product Derivatives 2007; 21(2):153-6.

26. Adrian WJ. A comparison of a wet pressure digestion method with other commonly used wet and dry-ashing methods. Analyst 1973; 98(1164):213-6.

27. Pradhan AK, Pradhan N, Sukla LB, Panda PK, Mishra BK. Inhibition of pathogenic bacterial biofilm by biosurfactant produced by Lysinibacillusfusiformis S9. Bioprocess and biosystems engineering. 2014; 37(2):13949. 
28. Bhattacharya D, Price DC, Chan CX, Qiu H, Rose N, Ball S, Weber AP, Arias MC, Henrissat B, Coutinho PM, Krishnan A. Genome of the red alga Porphyridiumpurpureum. Nature communications 2013; 4:1941.

29. Dhanalakshmi M. Phytochemistry And Antibacterial Activity Of Chlorosarcinopsis Species. International Journal of Scientific \& Technology Research 2013; 2(10):315-21.

30. Khalid MN, Shameel M, Ahmad VU, Shahzad S, Leghari SM. Bioactivity and phycochemistry of Gloeotrichiaraciborskii (Cyanophycota) from Sindh. International Journal of Phycology and Phycochemistry (Pakistan) 2010.

31. Ghazala B, Shameel MU, Choudhary MI, Shahzad SA, Leghari SM. Phycochemistry and bioactivity of certain freshwater green algae of Sindh. Pakistan Journal of Botany 2004; 35(5):695-704.

32. Fadoul HE, Juntawong N. Antimicrobial Activity of Extracts from Aquatic Algae Isolated From Salt Soil and Fresh Water in Thailand. International Journal of Research Studies in Biosciences (IJRSB) 2004; 2:149-52.

33. Vishnu N, Sumathi R. Isolation of fresh water microalgae Chlorella $\mathrm{sp}$ and its antimicrobial activity on selected pathogens. Int. J. Adv. Res. Biol. Sci 2014; 1(3):36-43.

34. Abedin RM, Taha HM. Antibacterial and antifungal activity of cyanobacteria and green microalgae. Evaluation of medium components by Plackett-Burman design for antimicrobial activity of Spirulinaplatensis. Global Journal of Biotechnology and Biochemistry 2008; 3(1):2231.

35. Ghasemi Y, Yazdi MT, Shafiee A, Amini M, Shokravi S, Zarrini G. Parsiguine, a novel antimicrobial substance from Fischerellaambigua. Pharmaceutical biology 2004; 42(4-5):318-22.

36. Ghasemi Y, Moradian A, Mohagheghzadeh A, Shokravi S, Morowvat MH. Antifungal and antibacterial activity of the microalgae collected from paddy fields of Iran: characterization of antimicrobial activity of Chroococcusdispersus. J Biol Sci 2007; 7:904-10.

37. Ördög $V$, Stirk WA, Lenobel $R$, Bancírová $M$, Strnad M, Van Staden J, Szigeti J, Németh L. Screening microalgae for some potentially useful agricultural and pharmaceutical secondary metabolites. Journal of applied phycology 2004; 16(4):309-14.

38. Goud MJ, Seshikala D, Charya MS. Antibacterial activity and biomolecular composition of certain fresh water microalgae collected from river Godavari (India). International Journal on Algae 2007; 9(4). 